\title{
Relationship Between Fibrinogen to Albumin Ratio and Prognosis of Gastrointestinal Stromal Tumors: A Retrospective Cohort Study
}

This article was published in the following Dove Press journal: Cancer Management and Research

\author{
Rui Li (iD ${ }^{1, *}$ \\ Shibo Song ${ }^{2, *}$ \\ Xiuwen $\mathrm{He}^{1}$ \\ Xiaolei Shi' \\ Zhen Sun' \\ Zhe $\mathrm{Li}^{\prime}$ \\ Jinghai Song (1D) \\ 'Department of General Surgery, Beijing \\ Hospital, National Center of \\ Gerontology, Peking University Fifth \\ School of Clinical Medicine, Beijing \\ 100730, People's Republic of China; \\ ${ }^{2}$ Department of Colorectal Surgery, \\ Tianjin Union Medical Center, Tianjin, \\ 300 I2I, People's Republic of China \\ *These authors contributed equally to \\ this work
}

Correspondence: Jinghai Song

Department of General Surgery, Beijing

Hospital, National Center of

Gerontology, Peking University Fifth

School of Clinical Medicine, No. I, Dahua

Road, Beijing 100730, People's Republic of

China

Tel +86-10-85136262

Fax +86-10-65132969

Email jhaisong2003@I63.com
Objective: The fibrinogen to albumin ratio (FAR) is an important parameter that reflects the coagulation state, systemic inflammation, and nutritional status of a patient and plays an essential role in tumor progression. Here, we evaluate the prognostic significance of FAR in gastrointestinal stromal tumor (GIST) patients that underwent radical surgery.

Methods: We retrospectively analyzed the data of 227 GIST patients that underwent radical surgery in Beijing Hospital from October 2004 to July 2018. We drew a curve of receiver operating characteristics to confirm the optimal critical values for hemoglobin $(\mathrm{Hb})$, prognostic nutrition index (PNI), and FAR. Cox regression analysis and the Kaplan-Meier method were used to assess the prognostic factors.

Results: The FAR optimal critical value for postoperative recurrence-free survival (RFS) was 0.09 . Many significant factors, including approach, the location and size of the tumor, mitotic index, risk classification, Hb levels, PNI, and recurrence, affect FAR. Multivariate analysis indicated that for patients with GISTs who underwent surgery, the tumor location (hazard ratio $[\mathrm{HR}]=3.393,95 \%$ confidence interval $[\mathrm{CI}]$ : $1.539-7.479, \mathrm{P}=0.002$ ), mitotic index $(\mathrm{HR}=4.788,95 \% \mathrm{CI}$ : 1.836-12.486, $\mathrm{P}=0.001)$, tumor rupture $(\mathrm{HR}=10.954,95 \% \mathrm{CI}$ : 2.170-55.296, $\mathrm{P}=0.004)$, and FAR ( $\mathrm{HR}=3.093$, 95\% CI: $1.303-7.339, \mathrm{P}=0.010)$ were independent factors affecting RFS. Moreover, the FAR remained of prognostic significance for GIST stratified by subgroup analysis.

Conclusion: Preoperative FAR is a reliable marker for evaluating the prognosis of GIST, the prognostic ability of FAR is significantly better than $\mathrm{Hb}$ and PNI.

Keywords: fibrinogen to albumin ratio, prognostic nutrition index, hemoglobin, prognosis, gastrointestinal stromal tumors

\section{Introduction}

In the digestive system, gastrointestinal stromal tumors (GISTs) are the most frequent mesenchymal tumors, with an annual incidence rate of 10-15 cases per one million people. Their malignant potential varies, ranging from mild benign lesions to fatal sarcomas. The primary treatment for resectable GISTs is margin negative complete resection. However, tumor relapse is still not uncommon after radical resection, particularly in high-risk patients. ${ }^{1,2}$ After recurrence, the median time to survive is less than two years, and the prognosis of GISTs is still poor. ${ }^{1,3}$ At present, the current parameters applied to predict and stratify the risk of tumor recurrence mainly include the size of the tumor, primary tumor site, mitotic index, and tumor rupture. ${ }^{4}$ However, these parameters require obtaining postoperative tumor specimens. Hence, it is 
necessary to probe for some economical, non-invasive, and convenient methods for predicting the prognosis of GIST patients as well as for screening patients in the high and middle category for adjuvant or even neoadjuvant therapy.

Several studies have demonstrated that a hypercoagulable state, systemic inflammation, and malnutrition are critically involved in the progression of tumors. $^{5-7}$ Tumor-related inflammation blood parameters such as prognostic nutritional index (PNI) and hemoglobin $\mathrm{Hb})$ are significantly correlated with the prognosis of patients with GISTs. ${ }^{8,9}$ Fibrinogen not only exerts an enormous function on inflammation and coagulation, but also participates in regulating cell proliferation, angiogenesis, and tumor cell migration. ${ }^{10,11}$ Albumin levels are key factors in assessing nutritional status and systemic inflammatory response. ${ }^{12}$ Moreover, many researchers have reported that preoperative FAR is upregulated in various cancer types, such as gastric, esophageal, and gallbladder cancer, and may indicate a poor prognosis. ${ }^{13-15}$

According to the above study, it can be speculated that FAR may be an important prognostic indicator for GISTs patients. Consequently, we retrospectively studied the prognostic FAR value in patients who had a radical operation with GIST.

\section{Materials and Methods}

\section{Patients}

The clinical and pathological parameters of 227 GIST patients that underwent curative surgical resection from October 2004 to July 2018 at Beijing Hospital were retrospectively included and analyzed. All of the patients were pathologically diagnosed with GISTs. The inclusion criteria were (1) patients with complete clinicopathological parameters and follow-up records; (2) patients with no neoadjuvant therapy before surgery; (3) patients $\geq 18$ years of age. The exclusion criteria were (1) patients with connective tissue disease and hematological diseases; (2) patients with other tumors; (3) patients with active inflammation; (4) patients who were treated with anticoagulants or albumin transfusions within 3 months before surgery; and (5) patients with R1 or R2 resection. The Beijing Hospital Medical Ethics Committee approved the study. Written informed consent was obtained from all patients before surgery.

\section{Data Collection}

The clinicopathological data obtained include sex, age, body mass index (BMI), Eastern Cooperative Oncology
Group (ECOG) performance status, surgical approach, the location and the size of the tumor, tumor rupture, risk classification, mitotic index (number of mitoses/50 highpower fields), $\mathrm{Hb}$, total lymphocyte count, fibrinogen, levels of albumin, and adjuvant imatinib treatment. $\mathrm{Hb}$, total lymphocyte count, fibrinogen, and albumin levels were collected within 7 days before surgery.

FAR was calculated as fibrinogen $(\mathrm{g} / \mathrm{L}) /$ albumin $(\mathrm{g} / \mathrm{L})$. PNI was measured as serum albumin $(\mathrm{g} / \mathrm{dl})+5 \times$ total lymphocyte count $\left(10^{9} / \mathrm{L}\right){ }^{16}$

\section{Follow-Up}

The patients were followed-up once every 3 months in the first 2 years, once every 6 months in the next 3 years, and annually thereafter. The deadline for follow-up was September 20, 2019. The follow-up program included abdominopelvic and chest magnetic resonance imaging (MRI) or computed tomography (CT) scan along with endoscopy and bone marrow scan when necessary. As the primary endpoint, the recurrence-free survival (RFS) refers to the period from surgery to the tumor recurrence.

\section{Statistical Analyses}

This study used the operating characteristics of receivers (ROC) to assess the FAR diagnostic value and determine the optimal critical point by estimating the Youden index (sensitivity + specificity-1). The exact test of fishers or Chi-square test was utilized to assess the relationship between FAR and clinicopathological parameters. The curves of Kaplan-Meier survival were plotted, and the Log rank test was conducted to study the statistical distinction between groups. Both univariate and multivariate analyses were utilized to ascertain the prognostic value of various clinicopathological data.

\section{Results}

\section{Clinicopathological Characteristics}

Of the 227 GIST patients included in the study, 124 (54.6\%) were male, and 103 (45.4\%) were female. The median age was 62 years (range: $18-83$ years), and the median BMI was $23.8 \mathrm{~kg} / \mathrm{m}^{2}$ (range: $16.4-36.6 \mathrm{~kg} / \mathrm{m} 2$ ). $130(57.3 \%)$ patients underwent open surgery and 97 (42.7\%) patients underwent laparoscopic surgery. The median tumor size was $5 \mathrm{~cm}$ (range: $0.5-29 \mathrm{~cm}$ ). According to the revised risk classification system of National Institute of Health (NIH), of the total 227 patients, $41(18.1 \%)$ were very low risk, 73 (32.2\%) 
Table I Correlation Between the FAR and Clinicopathological Characteristics

\begin{tabular}{|c|c|c|c|c|}
\hline \multirow[t]{2}{*}{ Factor } & \multirow{2}{*}{$\begin{array}{l}\text { Total } \\
(n=227)\end{array}$} & \multirow{2}{*}{$\begin{array}{l}F A R<0.09 \\
(n=\mid 46)\end{array}$} & \multirow{2}{*}{$\begin{array}{l}\text { FAR } \geq 0.09 \\
(n=8 I)\end{array}$} & \multirow[t]{2}{*}{ P value } \\
\hline & & & & \\
\hline \multicolumn{5}{|l|}{ Sex } \\
\hline Male & $\begin{array}{l}124 \\
(54.6 \%)\end{array}$ & 78 (62.9\%) & 46 (37.1\%) & 0.626 \\
\hline Female & $\begin{array}{l}103 \\
(45.4 \%)\end{array}$ & 68 (66\%) & 35 (34\%) & \\
\hline \multicolumn{5}{|l|}{ Age (yr) } \\
\hline$<60$ & $\begin{array}{l}95 \\
(41.9 \%)\end{array}$ & 67 (70.5\%) & 28 (29.5\%) & 0.098 \\
\hline$\geq 60$ & $\begin{array}{l}132 \\
(58.1 \%)\end{array}$ & $79(59.8)$ & 53 (40.2\%) & \\
\hline \multicolumn{5}{|l|}{ BMI $\left(\mathrm{kg} / \mathrm{m}^{2}\right)$} \\
\hline$<24$ & $\begin{array}{l}117 \\
(51.5 \%)\end{array}$ & 69 (59\%) & $48(4 \mid \%)$ & 0.083 \\
\hline$\geq 24$ & $\begin{array}{l}110 \\
(48.5 \%)\end{array}$ & 77 (70\%) & $33(30 \%)$ & \\
\hline \multicolumn{5}{|l|}{ ECOG score } \\
\hline $0-2$ & $\begin{array}{l}221 \\
(97.4 \%)\end{array}$ & $\begin{array}{l}143 \\
(64.7 \%)\end{array}$ & 78 (35.3\%) & 0.669 \\
\hline 3 & $6(2.4 \%)$ & $3(50 \%)$ & $3(50 \%)$ & \\
\hline \multicolumn{5}{|l|}{ Approach } \\
\hline Open & $\begin{array}{l}130 \\
(57.3 \%)\end{array}$ & 74 (56.9\%) & $56(43.1 \%)$ & 0.007 \\
\hline Laparoscopy & $\begin{array}{l}97 \\
(42.7 \%)\end{array}$ & 72 (74.2\%) & 25 (25.8\%) & \\
\hline \multicolumn{5}{|l|}{ Tumor location } \\
\hline Gastric & $\begin{array}{l}159 \\
(70 \%)\end{array}$ & $\begin{array}{l}110 \\
(69.2 \%)\end{array}$ & 49 (30.8\%) & 0.019 \\
\hline Extra-gastric & $68(30 \%)$ & $36(52.9 \%)$ & 32 (47.1\%) & \\
\hline \multicolumn{5}{|l|}{ Tumor rupture } \\
\hline No & $\begin{array}{l}224 \\
(98.7 \%)\end{array}$ & $\begin{array}{l}145 \\
(64.7 \%)\end{array}$ & 79 (35.3\%) & 0.290 \\
\hline Yes & $3(1.3 \%)$ & I (33.3\%) & $2(66.7 \%)$ & \\
\hline \multicolumn{5}{|l|}{ Tumor size $(\mathrm{cm})$} \\
\hline$<5$ & $\begin{array}{l}134 \\
(59 \%)\end{array}$ & $\begin{array}{l}101 \\
(75.4 \%)\end{array}$ & $33(24.6 \%)$ & $<0.001$ \\
\hline$\geq 5$ & $93(41 \%)$ & 45 (48.4\%) & 48 (5I.6\%) & \\
\hline \multicolumn{5}{|l|}{$\begin{array}{l}\text { Mitotic index } \\
(\times 50 \mathrm{HPF})\end{array}$} \\
\hline$<5$ & $\begin{array}{l}129 \\
(56.8 \%)\end{array}$ & 94 (72.9\%) & 35 (27.1\%) & 0.002 \\
\hline$\geq 5$ & $\begin{array}{l}98 \\
(43.2 \%)\end{array}$ & 52 (53.1\%) & 46 (46.9\%) & \\
\hline $\begin{array}{l}\text { Risk } \\
\text { classification }\end{array}$ & & & & \\
\hline
\end{tabular}

(Continued)
Table I (Continued).

\begin{tabular}{|c|c|c|c|c|}
\hline \multirow[t]{2}{*}{ Factor } & Total & FAR $<0.09$ & FAR $\geq 0.09$ & \multirow[t]{2}{*}{$P$ value } \\
\hline & $(n=227)$ & $(n=\mid 46)$ & $(n=8 I)$ & \\
\hline $\begin{array}{l}\text { Very low, low } \\
\text { Intermediate, } \\
\text { high }\end{array}$ & $\begin{array}{l}114 \\
(50.2 \%) \\
113 \\
(49.8 \%)\end{array}$ & $\begin{array}{l}87(76.3 \%) \\
59(52.2 \%)\end{array}$ & $\begin{array}{l}27(23.7 \%) \\
54(47.8 \%)\end{array}$ & $<0.001$ \\
\hline $\begin{array}{l}\mathrm{Hb}(\mathrm{g} / \mathrm{L}) \\
\quad<126.5 \\
\quad \geq 126.5\end{array}$ & $\begin{array}{l}102 \\
(44.9 \%) \\
125 \\
(55.1 \%)\end{array}$ & $\begin{array}{l}54(52.9 \%) \\
92(73.6 \%)\end{array}$ & $\begin{array}{l}48(47.1 \%) \\
33(26.4 \%)\end{array}$ & 0.001 \\
\hline $\begin{array}{l}\text { PNI } \\
\qquad 47.53 \\
\quad \geq 47.53\end{array}$ & $\begin{array}{l}82 \\
(36.1 \%) \\
145 \\
(63.9 \%)\end{array}$ & $\begin{array}{l}32(39 \%) \\
114 \\
(78.6 \%)\end{array}$ & $\begin{array}{l}50(6 \mid \%) \\
3 \mid(2 \mid .4 \%)\end{array}$ & $<0.001$ \\
\hline $\begin{array}{l}\text { Adjuvant } \\
\text { imatinib } \\
\text { No } \\
\text { Yes }\end{array}$ & $\begin{array}{l}176 \\
(77.5 \%) \\
51 \\
(22.5 \%)\end{array}$ & $\begin{array}{l}116 \\
(65.9 \%) \\
30(58.8 \%)\end{array}$ & $\begin{array}{l}60(34.1 \%) \\
21(41.2 \%)\end{array}$ & 0.352 \\
\hline $\begin{array}{l}\text { Recurrence } \\
\text { No } \\
\text { Yes }\end{array}$ & $\begin{array}{l}196 \\
(86.3 \%) \\
31 \\
(13.7 \%)\end{array}$ & $\begin{array}{l}\text { I38 } \\
(70.4 \%) \\
8(25.8 \%)\end{array}$ & $\begin{array}{l}58(29.6 \%) \\
23(74.2 \%)\end{array}$ & $<0.001$ \\
\hline
\end{tabular}

were low risk, $40(17.6 \%)$ were intermediate risk, and 73 (32.2\%) were high risk. The median Hb level was $129 \mathrm{~g} / \mathrm{L}$ (range: $38-168 \mathrm{~g} / \mathrm{L}$ ), and the median preoperative PNI level was 48.85 (range: $33.45-61.90$ ). The median preoperative FAR level was 0.08 (range: $0.04-0.27$ ). The median preoperative fibrinogen was $3.06 \mathrm{~g} / \mathrm{L}$ (range: $1.22-10.36 \mathrm{~g} / \mathrm{L})$, and $39(17.2 \%)$ was higher than the upper limit of normal $(4.00 \mathrm{~g} / \mathrm{L})$. The median preoperative albumin was $40 \mathrm{~g} / \mathrm{L}$ (range: $23-48 \mathrm{~g} / \mathrm{L}$ ), and 79 (34.8\%) was below the lower limit of normal $(40 \mathrm{~g} / \mathrm{L})$. Among the 113 patients of the moderate/high-risk group, 51 (45.1\%) patients received adjuvant imatinib treatment following surgery (Table 1).

\section{ROC Analysis}

According to the analysis of the ROC curve, 0.09 is the best FAR critical value (AUC: 0.767; 95\% CI 

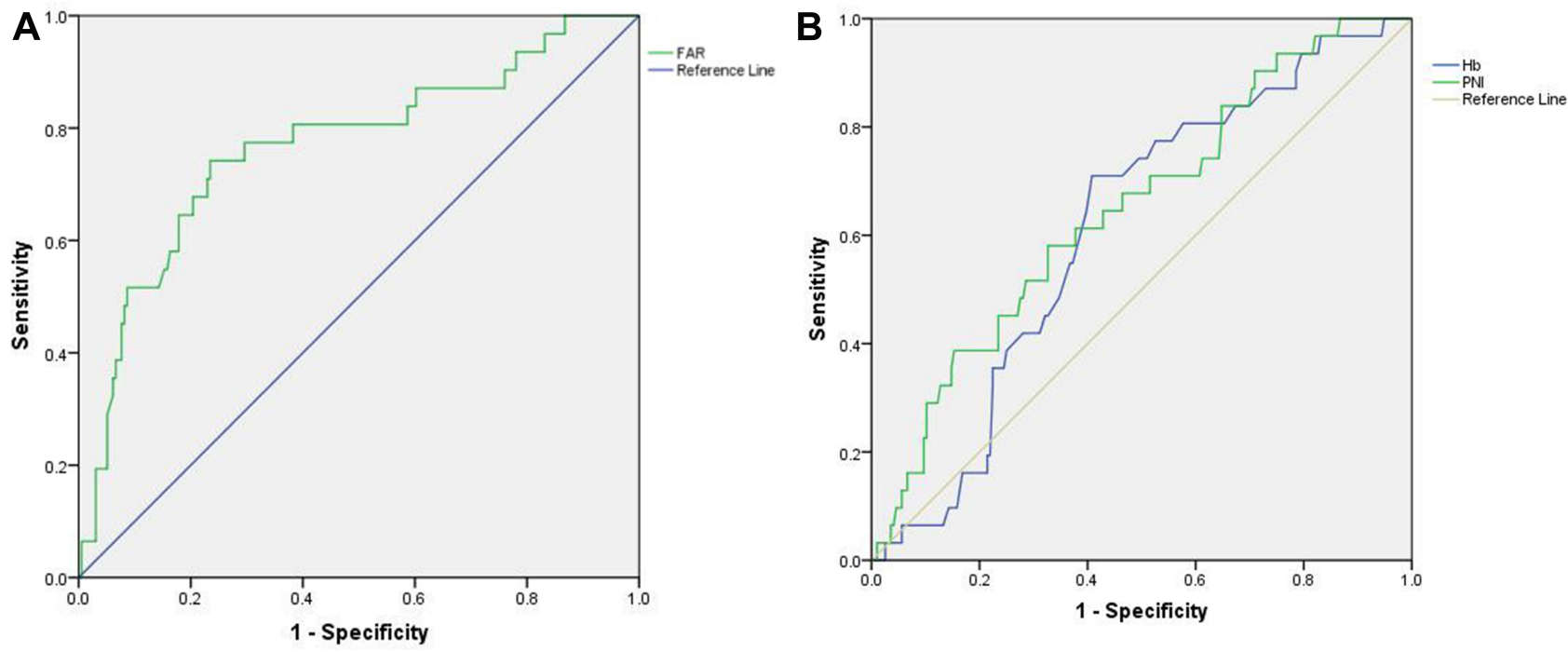

Figure I Optimal critical points of FAR (A), $\mathrm{Hb}$ and PNI (B) were applied using ROC curves.

Abbreviations: FAR, fibrinogen to albumin ratio; Hb, hemoglobin; PNI, prognostic nutritional index; ROC, receiver operating characteristics.

0.577-0.673; $\mathrm{p}<0.001$ ) (Figure 1A). According to this value as a critical criterion, 81 patients $(35.7 \%)$ were classified as high FAR group $(\geq 0.09)$ and 146 patients $(64.3 \%)$ were classified as a low FAR group $(<0.09)$. The best critical values for $\mathrm{Hb}$ and PNI were 127 (AUC: 0.613; 95\% CI: 0.518-0.707; $\mathrm{p}=0.044$ ) and 47.53 (AUC: 0.649; 95\% CI: 0.547-0.750; $\mathrm{p}=0.008$ ) (Figure 1B).

\section{Relationship Between the FAR and Clinicopathological Parameters}

The correlation between preoperative FAR and the clinical and pathological parameters are presented in Table 1 . Higher FAR was notably correlated with approach $(\mathrm{P}=0.007)$, size of the tumor $(\mathrm{P}<0.001)$, location of the tumor $(\mathrm{P}=0.019)$, mitotic index $(\mathrm{P}=0.002)$, risk classification $(\mathrm{P}<0.001)$, Hb levels $(\mathrm{P}=0.001)$, and $\mathrm{PNI}(\mathrm{P}<0.001)$. However, there were no visible associations of FAR with sex, age, BMI, ECOG score or tumor rupture (Ps $>0.05)$.

\section{Survival Analysis}

On the whole, one-year, three-year and five-year RFS rates were $96.8 \%, 88.5 \%$, and $82.9 \%$, respectively. The curves of Kaplan-Meier survival stratified by the FAR indicated that the RFS of the high FAR group is shorter than that of the low FAR group. One-year, three-year and five-year RFS rates for the high FAR group were $92.4 \%$, $77.9 \%$, and $67.1 \%$, respectively, and $99.2 \%, 94.8 \%$, and $93.3 \%$ for the low FAR group; overall, there is statistical significance in group differences $(\mathrm{P}<0.001$, Figure 2$)$. The RFS of patients with higher $\mathrm{Hb}$ or PNI was remarkably longer than that of patients with lower Hb or PNI ( $\mathrm{p}=0.001$, $\mathrm{p}=0.006$, Figure 2 ).

In Table 2, univariate analysis demonstrated that approach, tumor location, tumor rupture, tumor size, the mitotic index, Hb level, PNI, and FAR were important prognostic factors affecting RFS in GIST patients. In the multivariate analysis, tumor location $(\mathrm{HR}=3.393,95 \% \mathrm{CI}$ : 1.539-7.479, $\mathrm{p}=0.002)$, tumor rupture $(\mathrm{HR}=10.954,95 \%$ CI: $2.170-55.296, \mathrm{p}=0.004$ ), the mitotic index (HR $=4.788,95 \%$ CI: $1.836-12.486, \mathrm{p}=0.001$ ), and FAR (HR $=3.093,95 \%$ CI: $1.303-7.339, \mathrm{p}=0.010$ ) were independent prognostic factors for RFS, while the approach, tumor size, $\mathrm{Hb}$ level, and PNI were not.

To further examine the relationship between the preoperative FAR and RFS, we evaluated the prognostic significance of FAR by subgroup analyses. A shorter RFS was found in patients in the high FAR group who were part of either the very low/low/intermediate-risk classification subgroup or the high-risk classification subgroup ( $\mathrm{P}=0.018$ and $\mathrm{P}=0.020$, respectively) (Figure 3 ).

\section{Discussion}

During clinical work, the main prognostic factor for GIST patients is NIH risk classification, but it must be obtained from postoperative specimens, and it is impossible to evaluate the patient's prognosis and guide treatment before surgery. Thus, some researchers began to explore bloodbased biomarkers. For example, $\mathrm{Hb}$ and PNI are independent prognostic factors in GIST patients. FAR has shown 

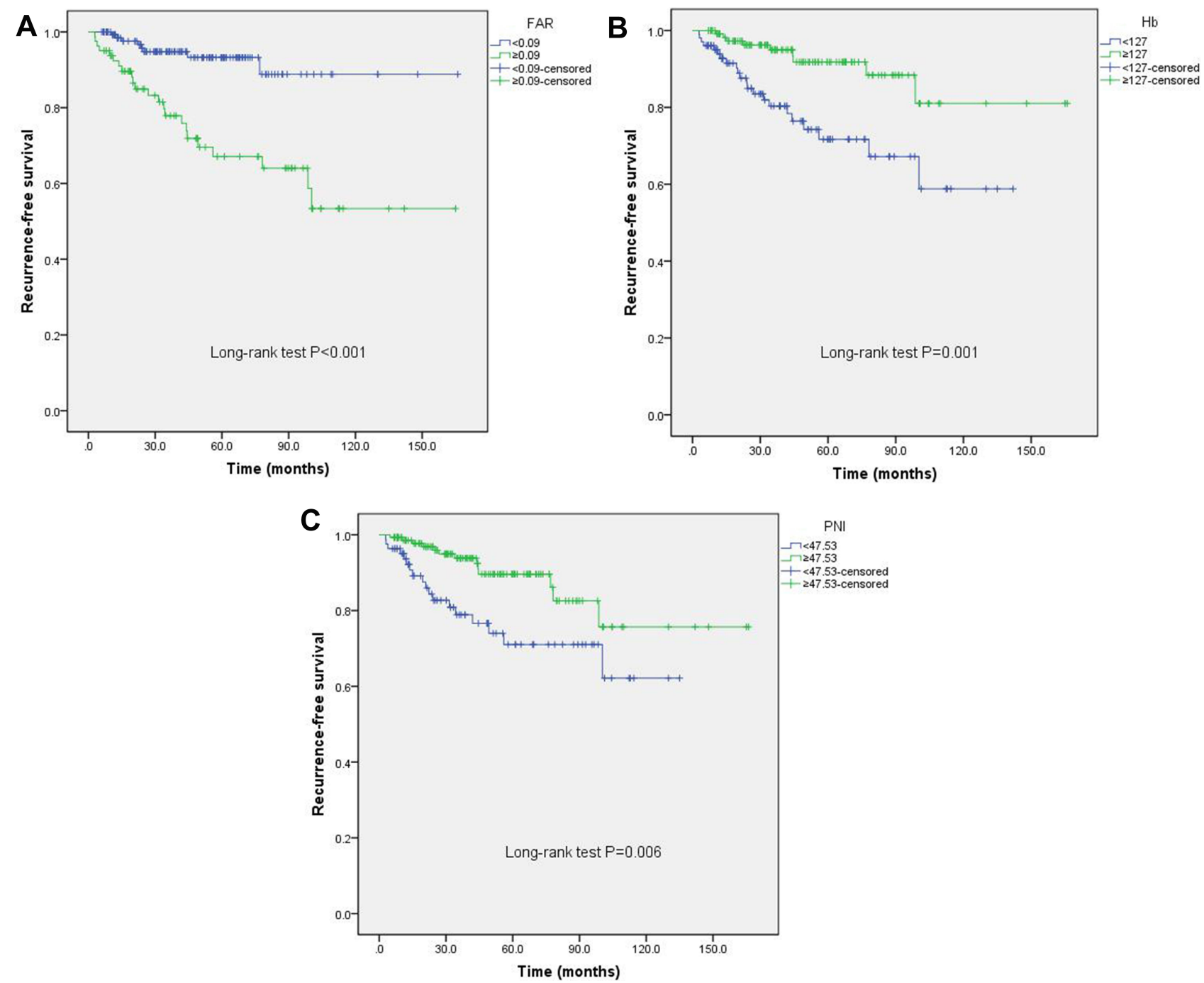

Figure 2 Kaplan-Meier curves for recurrence-free survival according to the FAR (A), Hb (B), and PNI (C). Abbreviations: FAR, fibrinogen to albumin ratio; $\mathrm{Hb}$, hemoglobin; PNI, prognostic nutritional index.

significant prognostic value in gastric cancer, esophageal squamous cell carcinoma, gallbladder cancer, and hepatocellular carcinoma. ${ }^{14,15,17,18}$ Therefore, we speculated that FAR may have significant prognostic value in patients who went through radical surgery with GIST and proved this hypothesis through retrospective studies. According to the information we have, this is the first time that a study is assessing FAR's prognostic value in GIST patients.

Our study indicated that the optimal FAR critical value in GIST patients was 0.09 , which is within the range of that in other digestive system tumors (range: $0.06-0.11) .{ }^{14,15,17,18}$ The differences in the FARs between different digestive system tumors are slight; we speculate that these slight differences may be due to different biological behaviors of different tumors or the limitations of various studies. Moreover, $\mathrm{Hb}^{8}$ and $\mathrm{PNI}^{9}$ of GIST patients who had surgery in previous studies were demonstrated to be independent prognostic factors. However, our study showed significantly different results. First of all, the AUC of FAR has a higher value than PNI and $\mathrm{Hb}$; at the same time, the p-value of FAR was also lower than $\mathrm{Hb}$ and PNI. Second, multivariate analysis revealed that FAR was an independent predictor, however, $\mathrm{Hb}$ and PNI were not. Therefore, the prognostic capability of FAR was significantly greater than that of $\mathrm{Hb}$ and PNI.

Our study also demonstrated that the FAR indicates that the tumor has more aggressive behavior which was related to the progression of GISTs, as a higher FAR was significantly related to the larger size of the tumor, higher risk classification and larger mitotic index, as well as a lower $\mathrm{Hb}$ level, lower PNI, and worse prognosis. These results further supported previous researches. ${ }^{17}$ Moreover, subgroup 
Table 2 Univariate and Multivariate Analysis of Clinicopathological Variables Related to Recurrence-Free Survival

\begin{tabular}{|c|c|c|c|c|}
\hline \multirow[t]{2}{*}{ Variables } & \multicolumn{2}{|c|}{ Univariate Analysis } & \multicolumn{2}{|l|}{$\begin{array}{l}\text { Multivariate } \\
\text { Analysis }\end{array}$} \\
\hline & HR (95\% CI) & $\mathbf{P}$ & HR $(95 \% \mathrm{CI})$ & $P$ \\
\hline $\begin{array}{l}\text { Sex } \\
\qquad \text { Male } \\
\text { Female }\end{array}$ & $\begin{array}{l}\text { I } \\
0.835 \\
(0.405-1.724)\end{array}$ & 0.626 & & \\
\hline $\begin{array}{c}\text { Age (yr) } \\
<60 \\
\geq 60\end{array}$ & $\begin{array}{l}\text { I } \\
\text { I.I54 } \\
(0.559-2.380)\end{array}$ & 0.699 & & \\
\hline $\begin{array}{l}\text { BMI }\left(\mathrm{kg} / \mathrm{m}^{2}\right) \\
\quad<24 \\
\quad \geq 24\end{array}$ & $\begin{array}{l}\text { I } \\
0.759 \\
(0.372-1.549)\end{array}$ & 0.449 & & \\
\hline $\begin{array}{l}\text { ECOG score } \\
0-2 \\
3\end{array}$ & $\begin{array}{l}1.553 \\
(0.211-11.455)\end{array}$ & 0.666 & & \\
\hline $\begin{array}{l}\text { Approach } \\
\text { Open } \\
\text { Laparoscopy }\end{array}$ & $\begin{array}{l}I \\
0.203 \\
(0.07 I-0.580)\end{array}$ & 0.003 & $\begin{array}{l}\text { I } \\
0.709 \\
(0.204-2.468)\end{array}$ & 0.589 \\
\hline $\begin{array}{l}\text { Tumor } \\
\text { location } \\
\text { Gastric } \\
\text { Extra- } \\
\text { gastric }\end{array}$ & $\begin{array}{l}\text { I } \\
3.716 \\
(1.824-7.569)\end{array}$ & $<0.001$ & $\begin{array}{l}1 \\
3.393 \\
(1.539-7.479)\end{array}$ & 0.002 \\
\hline $\begin{array}{l}\text { Tumor } \\
\text { rupture } \\
\text { No } \\
\text { Yes }\end{array}$ & $\begin{array}{l}\text { I } \\
10.612 \\
(2.494-45.160)\end{array}$ & 0.001 & $\begin{array}{l}\text { I } \\
10.954 \\
(2.170-55.296)\end{array}$ & 0.004 \\
\hline $\begin{array}{l}\text { Tumor size } \\
\begin{array}{l}(\mathrm{cm}) \\
<5 \\
\geq 5\end{array}\end{array}$ & $\begin{array}{l}\text { I } \\
5.589 \\
(2.406-12.983)\end{array}$ & $<0.001$ & $\begin{array}{l}\text { I } \\
1.932 \\
(0.726-5.142)\end{array}$ & 0.187 \\
\hline $\begin{array}{l}\text { Mitotic index } \\
(\times 50 \mathrm{HPF}) \\
\quad<5 \\
\geq 5\end{array}$ & $\begin{array}{l}\text { I } \\
6.642 \\
(2.721-16.209)\end{array}$ & $<0.001$ & $\begin{array}{l}1 \\
4.788 \\
(1.836-12.486)\end{array}$ & 0.001 \\
\hline $\begin{aligned} \mathrm{Hb} & (\mathrm{g} / \mathrm{L}) \\
& <126.5\end{aligned}$ & I & & I & \\
\hline
\end{tabular}

(Continued)
Table 2 (Continued).

\begin{tabular}{|c|c|c|c|c|}
\hline \multirow[t]{2}{*}{ Variables } & \multicolumn{2}{|c|}{ Univariate Analysis } & \multicolumn{2}{|l|}{$\begin{array}{l}\text { Multivariate } \\
\text { Analysis }\end{array}$} \\
\hline & HR (95\% Cl) & $\mathbf{P}$ & HR (95\% Cl) & $P$ \\
\hline$\geq 126.5$ & $\begin{array}{l}0.288 \\
(0.133-0.627)\end{array}$ & 0.002 & $\begin{array}{l}0.435 \\
(0.170-1.117)\end{array}$ & 0.084 \\
\hline $\begin{array}{l}\text { PNI } \\
\qquad 47.53 \\
\geq 47.53\end{array}$ & $\begin{array}{l}\text { I } \\
0.384 \\
(0.188-0.784)\end{array}$ & 0.009 & $\begin{array}{l}\text { I } \\
\text { I.827 } \\
(0.749-4.457)\end{array}$ & 0.185 \\
\hline $\begin{array}{l}\text { FAR } \\
\begin{array}{r}<0.09 \\
\geq 0.09\end{array}\end{array}$ & $\begin{array}{l}1 \\
4.819 \\
(2.146-10.822)\end{array}$ & $<0.001$ & $\begin{array}{l}1 \\
3.093 \\
(1.303-7.339)\end{array}$ & 0.01 \\
\hline $\begin{array}{l}\text { Adjuvant } \\
\text { imatinib } \\
\text { No } \\
\text { Yes }\end{array}$ & $\begin{array}{l}\text { I } \\
\text { I.326 } \\
(0.590-2.981)\end{array}$ & 0.495 & & \\
\hline
\end{tabular}

analysis revealed that a higher FAR was related to shorter RFS of patients who were classified within the very low/ low/intermediate and high-risk subgroups. The FAR can not only be used for prognosis evaluation of patients with GIST before the operation, but can also be considered to be added to the current risk classification system, to participate in further risk stratification of high-risk patients, and to guide neoadjuvant and adjuvant therapies which are more important for patients who cannot undergo surgery and obtain pathological specimens.

Several studies have indicated that fibrinogen may promote the progression of various tumors. As an important part of the coagulation system and acute-phase response protein, fibrinogen could upgrade pro-inflammatory cytokines in certain tumor cells, which promote the inflammatory response that is considered to supply a favorable tumor microenvironment for promoting tumor proliferation, invasion, and metastasis. ${ }^{10,19-22}$ As an extracellular matrix protein, fibrinogen can induce the transition of epithelial mesenchyme to promote tumor cells migration and invasion, which involve modulation of the expression of E-cadherin and vimentin. ${ }^{11,23}$ Another animal experiment using a mouse model of fibrinogen-deficiency showed that the internal environment without fibrinogen can inhibit the metastasis of tumor cells and can help the establishment of subsequent micrometastasis. ${ }^{24}$ Fibrinogen also exerts an 

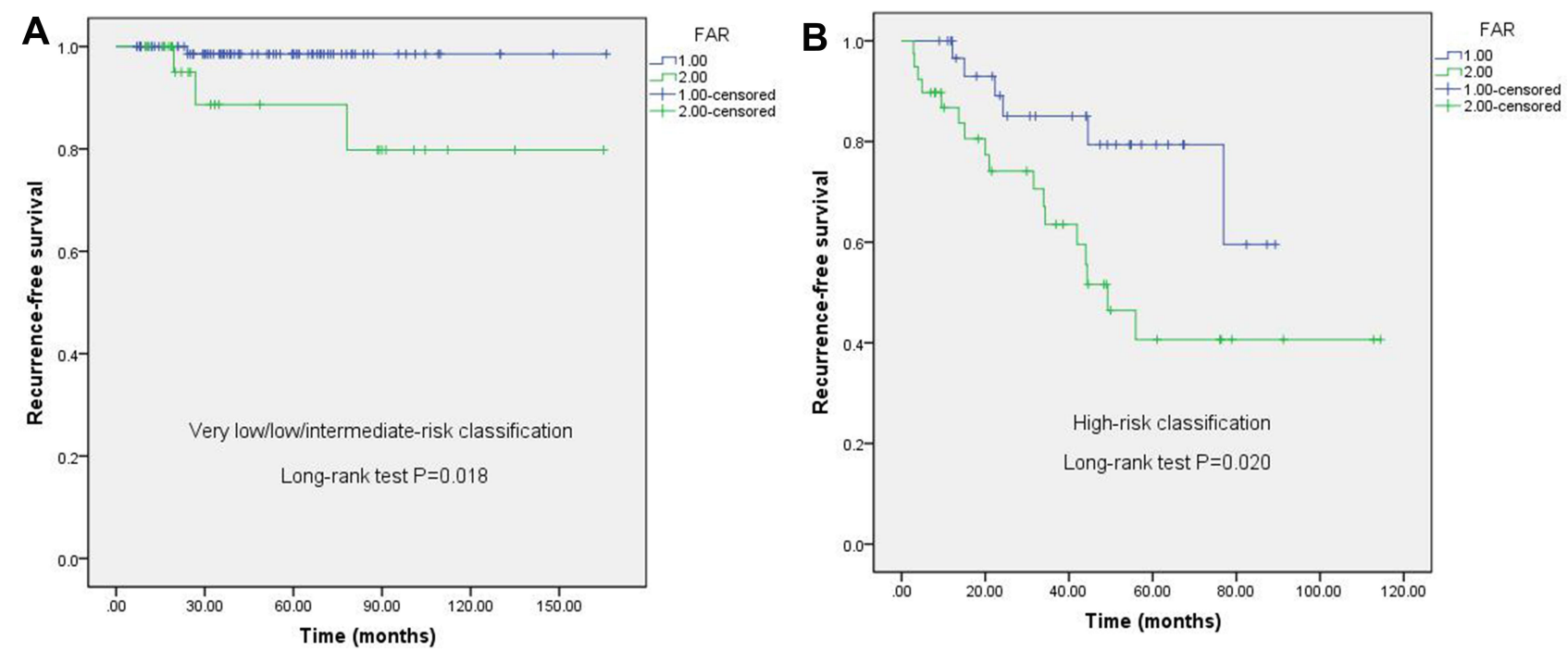

Figure 3 Prognostic data of the pretreatment FAR in different risk classification subgroups. (A) Very low/low/intermediate-risk classification subgroup; (B) high-risk classification subgroup.

Abbreviation: FAR, fibrinogen to albumin ratio.

enormous function on angiogenesis, which is critically involved in tumorigenesis and progression of the tumor. Besides, high fibrinogen levels can promote platelet adhesion to cancer cells, thereby facilitating the metastasis. ${ }^{25}$ However, the exact molecular mechanism by which fibrinogen is involved in tumor progression requires further study.

As a chronic phase protein, albumin is considered to be a measure of systemic inflammation, liver function, and nutritional status. The relationship between albumin and tumors is complex, albumin can be considered both consequence and cause of the presence of an advanced tumor. On the one hand, advanced tumors lead to protein degradation including albumin mediated by the ubiquitin-proteasome pathway. ${ }^{26}$ On the other hand, hypoalbuminemia promotes various tumor progression. Numerous researches have shown that it is a stabilizer for DNA proliferation and cell growth, and it exerts antioxidant functions on carcinogens and adjusted immune responses accordingly; which is of great significance in antitumor response. ${ }^{27-29}$ Hypoalbuminemia caused by malnutrition and poor performance was shown to be related to postoperative complications and poor prognosis in patients with various tumors, especially in those with gastrointestinal tumors. ${ }^{30-33}$

For GISTs, the main molecular mechanism of tumorigenesis is that $c-K I T$ gene mutation activates the phosphoinositide 3-kinase (PI3K) pathway, thereby regulating the cell cycle, making anti-apoptotic signals out of control, and stimulating tumor cell proliferation. ${ }^{1,34}$ Moreover, the PI3K pathway can also promote the production of inflammatory cytokines, inflammatory cell recruitment and angiogenesis, which contributes to form a tumor environment favorable to tumor progression. ${ }^{35}$ However, the molecular mechanism of inflammation and tumor interaction in GISTs needs to be further explored.

As an important therapy for GIST, adjuvant imatinib is believed to significantly improve the prognosis of GIST patients, however, its benefit was not shown in our multivariate analysis. The cases in this study were collected from 2004 to 2018, during which the indications and dosage of imatinib changed reasonably. Even to this day, the controversy about the specific use strategy of imatinib has not completely ended. We speculate that the above situation and insufficient follow-up time and the number of cases with adjuvant imatinib are possible reasons. Being a single-center retrospective study, the small sample size is a limitation of our research. In addition, because of adverse drug reactions or high drug costs, some of the intermediate and high-risk cases included in this study failed to receive standard adjuvant treatment.

\section{Conclusion}

The FAR is correlated with the progression of tumors. Also, it can be used as an independent indicator to predict RFS in GIST patients receiving radical surgery. Besides, our study indicated that the prognostic ability of FAR is significantly better than $\mathrm{Hb}$ and PNI. We recommend adding it to the current risk classification to further stratify high-risk patients and guide neoadjuvant therapy and adjuvant therapy. FAR as 
an assessment tool to guide the future treatment of GIST still needs a large clinical prospective study for verification so that it can be applied to the patients' benefit.

\section{Abbreviations}

AUC, area under the curve; CI, confidence interval; CT, computed tomography; FAR, fibrinogen to albumin ratio; GIST, gastrointestinal stromal tumor; BMI, body mass index; ECOG, Eastern Cooperative Oncology Group; Hb, hemoglobin; HR, hazard ratio; RFS, recurrence-free survival; ROC, receiver operating characteristics; PNI, prognostic nutrition index; PI3K, phosphoinositide 3-kinase.

\section{Ethics Approval and Consent to Participate}

All procedures performed in studies involving human participants were in accordance with the ethical standards of the institutional and/or national research committee and with the 1964 Helsinki declaration and its later amendments or comparable ethical standards.

\section{Disclosure}

The authors report no conflicts of interest in this work.

\section{References}

1. Joensuu H, Hohenberger P, Corless CL. Gastrointestinal stromal tumour. Lancet. 2013;382(9896):973-983. doi:10.1016/S01406736(13)60106-3

2. Zhang X, Ning L, Hu Y, et al. Prognostic factors for primary localized gastrointestinal stromal tumors after radical resection: Shandong gastrointestinal surgery study group, Study 1201. Ann Surg Oncol. 2020;27 (8):2812-2821. doi:10.1245/s10434-020-08244-9

3. Joensuu H, Vehtari A, Riihimaki J, et al. Risk of recurrence of gastrointestinal stromal tumour after surgery: an analysis of pooled population-based cohorts. Lancet Oncol. 2012;13(3):265-274. doi:10.1016/S1470-2045(11)70299-6

4. Joensuu H. Risk stratification of patients diagnosed with gastrointestinal stromal tumor. Hum Pathol. 2008;39(10):1411-1419. doi:10.1016/ j.humpath.2008.06.025

5. Balkwill F, Mantovani A. Inflammation and cancer: back to Virchow? Lancet. 2001;357(9255):539-545. doi:10.1016/S0140-6736(00)040460

6. Jain A, Zhang Q, Toh HC. Awakening immunity against cancer: a 2017 primer for clinicians. Chin J Cancer. 2017;36(1):67. doi:10.1186/s40880-017-0233-4

7. Itami Y, Miyake M, Tatsumi Y, et al. Preoperative predictive factors focused on inflammation-, nutrition-, and muscle-status in patients with upper urinary tract urothelial carcinoma undergoing nephroureterectomy. Int $J$ Clin Oncol. 2019;24(5):533-545. doi:10.1007/s10147-018-01381-y

8. Duensing A, Stotz M, Liegl-Atzwanger B, et al. Blood-based biomarkers are associated with disease recurrence and survival in gastrointestinal stroma tumor patients after surgical resection. PLoS One. 2016;11(7):e0159448. doi:10.1371/journal.pone.0159448
9. Sun J, Mei Y, Zhu Q, et al. Relationship of prognostic nutritional index with prognosis of gastrointestinal stromal tumors. $J$ Cancer. 2019;10(12):2679-2686. doi:10.7150/jca.32299

10. Dolan RD, McSorley ST, Horgan PG, Laird B, McMillan DC. The role of the systemic inflammatory response in predicting outcomes in patients with advanced inoperable cancer: systematic review and meta-analysis. Crit Rev Oncol Hematol. 2017;116:134-146. doi:10.1016/j.critrevonc.2017.06.002

11. Shu YJ, Weng H, Bao RF, et al. Clinical and prognostic significance of preoperative plasma hyperfibrinogenemia in gallbladder cancer patients following surgical resection: a retrospective and in vitro study. BMC Cancer. 2014;14:566. doi:10.1186/1471-2407-14-566

12. Mantovani A, Allavena P, Sica A, Balkwill F. Cancer-related inflammation. Nature. 2008;454(7203):436-444. doi:10.1038/ nature 07205

13. QF Gao, Qia JC, Huang XH, et al. The predictive and prognostic role of a novel ADS score in esophageal squamous cell carcinoma patients undergoing esophagectomy. Cancer Cell Int. 2018;18:153. doi:10.1186/s12935-018-0648-2

14. Zhang J, Li SQ, Liao ZH, et al. Prognostic value of a novel FPR biomarker in patients with surgical stage II and III gastric cancer. Oncotarget. 2017;8(43):75195-75205. doi:10.18632/ oncotarget.20661

15. Xu WY, Zhang HH, Xiong JP, et al. Prognostic significance of the fibrinogen-to-albumin ratio in gallbladder cancer patients. World $J$ Gastroenterol. 2018;24(29):3281-3292. doi:10.3748/wjg.v24. i29.3281

16. Onodera T, Goseki N, Kosaki G. [Prognostic nutritional index in gastrointestinal surgery of malnourished cancer patients].. Nihon Geka Gakkai Zasshi. 1984;85(9):1001-1005.

17. Tan Z, Zhang M, Han Q, et al. A novel blood tool of cancer prognosis in esophageal squamous cell carcinoma: the Fibrinogen/Albumin Ratio. J Cancer. 2017;8(6):1025-1029. doi:10.7150/jca.16491

18. Xu Q, Yan Y, Gu S, et al. A novel inflammation-based prognostic score: the fibrinogen/albumin ratio predicts prognoses of patients after curative resection for hepatocellular carcinoma. $J$ Immunol Res. 2018;2018:4925498. doi:10.1155/2018/4925498

19. Kieliszek M, Lipinski B. Pathophysiological significance of protein hydrophobic interactions: an emerging hypothesis. Med Hypotheses. 2018;110:15-22. doi:10.1016/j.mehy.2017.10.021

20. J T, K P, PM S, et al. Fibrinogen and fibrin induce synthesis of proinflammatory cytokines from isolated peripheral blood mononuclear cells. Thromb Haemost. 2007;97(5):822-829. doi:10.1160/TH0701-0039

21. Ridker PM, Howard CP, Walter V, et al. Effects of interleukin-1 $\beta$ inhibition with canakinumab on hemoglobin A1c, lipids, C-reactive protein, interleukin- 6 , and fibrinogen: a phase IIb randomized, placebo-controlled trial. Circulation. 2012;126(23):2739-2748. doi:10.1161/CIRCULATIONAHA.112.122556

22. Adams RA, Schachtrup C, Davalos D, Tsigelny I, Akassoglou K. Fibrinogen signal transduction as a mediator and therapeutic target in inflammation: lessons from multiple sclerosis. Curr Med Chem. 2007;14(27):2925-2936. doi:10.2174/092986707782360015

23. Z F, W Y, S P, et al. Fibrinogen promotes malignant biological tumor behavior involving epithelial-mesenchymal transition via the p-AKT/ p-mTOR pathway in esophageal squamous cell carcinoma. $J$ Cancer Res Clin Oncol. 2017;143(12):2413-2424. doi:10.1007/s00432-0172493-4

24. Palumbo JS, Potter JMKaplan LS et al. Spontaneous hematogenous and lymphatic metastasis, but not primary tumor growth or angiogenesis, is diminished in fibrinogen-deficient mice. Cancer Res. 2002;62 (23):6966-6972.

25. Zheng S, Shen J, Jiao Y, et al. Platelets and fibrinogen facilitate each other in protecting tumor cells from natural killer cytotoxicity. Cancer Sci. 2009;100(5):859-865. doi:10.1111/j.13497006.2009.01115.x 
26. Zhang L, Tang H, Kou Yet al,. MG132-mediated inhibition of the ubiquitin-proteasome pathway ameliorates cancer cachexia. J Cancer Res Clin Oncol. 2013;139(7):1105-1115. doi:10.1007/s00432-0131412-6

27. Garcia-Martinez R, Andreola F, Mehta G, et al. Immunomodulatory and antioxidant function of albumin stabilises the endothelium and improves survival in a rodent model of chronic liver failure. J Hepatol. 2015;62(4):799-806. doi:10.1016/j.jhep.2014.10.031

28. Reebye V, Sætrom P, Mintz PJ, et al. Novel RNA oligonucleotide improves liver function and inhibits liver carcinogenesis in vivo. Hepatology (Baltimore, Md). 2014;59(1):216-227. doi:10.1002/ hep. 26669

29. Nojiri S, Joh T. Albumin suppresses human hepatocellular carcinoma proliferation and the cell cycle. Int J Mol Sci. 2014;15(3):5163-5174. doi:10.3390/ijms 15035163

30. Garcia-Martinez R, Caraceni P, Bernardi M, Gines P, Arroyo V, Jalan R. Albumin: pathophysiologic basis of its role in the treatment of cirrhosis and its complications. Hepatology. 2013;58 (5):1836-1846. doi:10.1002/hep.26338
31. Xiao S, Feng F, Liu N, et al. Preoperative albumin level is superior to albumin-globulin ratio as a predicting indicator in gastric cancer patients who underwent curative resection. Cancer Manag Res. 2019;11:9931-9938. doi:10.2147/CMAR.S230741

32. Gatta A, Verardo A, Bolognesi M. Hypoalbuminemia. Intern Emerg Med. 2012;7(Suppl 3):S193-199. doi:10.1007/s11739-012-0802-0

33. Gonzalez-Trejo S, Carrillo JF, Carmona-Herrera DD, et al. Baseline serum albumin and other common clinical markers are prognostic factors in colorectal carcinoma: a retrospective cohort study. Medicine (Baltimore). 2017;96(15):6610-6617. doi:10.1097/ MD.0000000000006610

34. Corless CL, Barnett CM, Heinrich MC. Gastrointestinal stromal tumours: origin and molecular oncology. Nat Rev Cancer. 2011;11 (12):865-878.

35. Fruman DA, Rommel C. PI3K and cancer: lessons, challenges and opportunities. Nat Rev Drug Discov. 2014;13(2):140-156.

\section{Publish your work in this journal}

Cancer Management and Research is an international, peer-reviewed open access journal focusing on cancer research and the optimal use of preventative and integrated treatment interventions to achieve improved outcomes, enhanced survival and quality of life for the cancer patient.
The manuscript management system is completely online and includes a very quick and fair peer-review system, which is all easy to use. Visit http://www.dovepress.com/testimonials.php to read real quotes from published authors. 